\title{
Work Becomes Obligation for the Family: Analysis of Work- Family Balance on Fishermen's Wife
}

\author{
Sri Rahayu ${ }^{1 *}$ \\ ${ }^{1}$ Faculty of Economics and Management, Samawa University, Sumbawa, Indonesia
}

\section{A R T I C L E I N F O}

Article history:

Received 27 September 2020

Received in revised form 05 October 2020

Accepted 18 October 2020

Available online 01

November 2020

Keywords:

Family, Fishermen's, Woman

\begin{abstract}
A B S T R A C T
This study aims to reveal the experiences of fishermen's wives working in balancing the dual roles of work and family, as well as the factors that can influence it. This study uses a qualitative method with a phenomenological approach. The data analysis technique in this research uses the Interpretative Phenomenological Analysis (IPA) technique. The researcher managed to conclude that there were five main themes including; a picture of life at work, the dynamics of life in the family, a picture of life undergoing multiple roles, the factors that influence the dual role of fishermen's wives and exploration of achieving balance in playing multiple roles. The role of being a housewife in a family and working to help the family economy begins when fishermen's wives choose to work after marriage. The encouragement of fishermen's wives to keep working after marriage is due to uncertain family income. This is also because their husband's catch depends on the season. Erratic season affects the
\end{abstract} fishermen's catch. One of the encouragement of fishermen's wives to work is to actualize their potential and abilities and to meet family needs

Copyright (c) Universitas Pendidikan Ganesha. All rights reserved.

\section{Introduction}

The times have made women enter the world of work, the phenomenon of working women is a common thing in today's modern era. Some women are even able to hold important positions in several positions, at this time, there is also a shift in the types of work done by women, so that jobs that were previously dominant were done by men, now many have been done by women, starting from women. being a doctor, construction expert, doctor or economist, until manual labour is done by women, such as being a coolie, a pedicab driver, and even being a motorcycle taxi driver have been entered by women. The role of women is growing along with the times (Farihah, 2015; Gauche et al., 2017; Zuhriah, 2016). The opportunity for women to work outside the home is getting bigger with advances in various fields and sectors of life. There have been many changes and advances in various fields and sectors of life, one of which is the emergence of the phenomenon of the increasing number of women working and the increasing number of women who have succeeded in entering the types of work that are rarely occupied by women. Women work not only to meet economic needs, but also for self-actualization, even a woman can be a positive model for child development (Anoraga, 2009; Zuhriah, 2016). However, the possible disadvantage is that women who have multiple roles will face life problems at work and problems in the family, such as conflicts between the role of work and the role of women in the family, reducing time for their husbands and children. Woman who works, has a dual role that must be carried out at the same time. A female lecturer, on the one hand, wants to achieve optimal performance in the functions of teaching, research, service and other supporting elements. On the other hand, at the same time, also want to succeed in a role in the household (Ariwidodo, 2016; Handayani et al., 2012). In accordance with the growing and developing socio-cultural conditions, there are three main elements of women's duties in the household, namely as wives, educators and as housewives. 
The trade sector also provides a very large opportunity for the involvement of women because jobs in the trade sector match women's natural physical abilities. Many women today are involved in the trade sector. Women have an attractiveness in the trade sector, for women who have their own income, on the one hand women can exploit and develop their potential, on the other hand women can earn their own income, thus women can meet their needs and even contribute their income to meet economic needs families and women are economically independent (Farihah, 2015; Herdiansyah, 2016). Women who are involved in the trade sector (public role) generally have a higher bargaining position than women who are only involved in the domestic sector (domestic role). The involvement of fishermen's wives in the public sphere of the family is not only beneficial for household survival, increased self-capacity and social status in the social structure of society, but can also contribute to the socio-economic dynamics of local communities (Hidayati, 2015; Mulyadi, 2011). Thus, women are not only a socio-cultural potential, however, a very potential in economic development. Psychologically, the dynamics of women's roles can provide self-confidence, motivation and appreciation and self-esteem for women that are relatively the same as men.

The decision of a married woman to work makes women have multiple roles related to fulfilling roles in work and in the family. The dual role played by women is a double burden, namely the role burden caused by domestic (family) duties that women must prioritize in addition to public duties (work) (Herdiansyah, 2016; Saleha et al., 2008). This decision is not a wrong decision, but the most important thing is the ability to balance the two responsibilities it carries, namely between work and family. Changes in household economic dependence can affect the role, power or authority structure between men and women, which is fundamentally a differentiation process as it is very relevant for men and women who are bound in a marriage. It is important for women to have their own income, because this will affect autonomy in decision-making and social change, and women get opportunities to compete and move to higher levels, both in the family and in society (Hidayati, 2015; Najmi \& Fitrisia, 2019). In fact, in carrying out work roles and personal lives, women encounter obstacles in their efforts to create a balance between the two roles, the role of working women and the role of housewives. Work and family balance reflect individual satisfaction in both family and work roles, by minimizing conflict. Multiple role conflicts have a positive effect on job stress, this indicates that the greater the dual role conflict causes increased work stress (Kumalasari et al., 2018; Murtiningrum, 2005).

Work-Family Balance is an overall assessment of the level of effectiveness and satisfaction of individuals in carrying out roles in the realm of work and family in accordance with their individual life values at each point they have determined. This balance is shown by the achievement of individual satisfaction and the existence of effective individual involvement in each role played, in accordance with the priority values of individual life both in the realm of work and in the realm of the family. The success of women who are married and working in achieving a balance between work and family is influenced by the success of women in implementing strategies to overcome work and family conflicts (Andrade, 2018; Greenhaus \& Allen, 2011; Valk \& Srinivasan, 2011). In the coastal area of Labuhan Bada's District, Sumbawa Regency, the role of women or fishermen's wives is generally very strategic, as an important source of family income. The fish catch that tends to be erratic and often experiences a dry season, this causes the role of fishermen's wives who work in the public sector to be able to contribute to meet the increasingly burdensome needs of daily life.

The economic contribution of coastal women to community life is a form of self-actualization capacity as a social reality that cannot be ignored. They can be considered as empowerment assets. At the social level of coastal communities, the dominance of coastal women in the economic sector has positioned them as important contributors to the economic dynamics of coastal areas. The stability of coastal economic dynamics greatly determines the distribution of income and the welfare of coastal communities (Ariwidodo, 2016). Fishermen's wives play an important role in maintaining the survival of their household, to help the family's economy, fishermen's wives work by trading or selling their husband's fish catch from the rising of the sun to the setting of the sun (Farihah, 2015; Najmi \& Fitrisia, 2019), this is done by fishermen's wives in Labuhan Bada's District for their families to be able to fulfill their daily needs, however, the fishermen's wives in Labuhan Bada's Sub-district even though they still work to sell the fish that their husbands catch in the market, they do not forget their duties as housewives, they are forced to work helping their husbands for the sake of their loved ones.

The success of women in balancing the dual roles between work and family cannot be separated from the influence and support of their husbands. Fishermen households have long been known to be classified as poor, in managing fishermen's households, it is very possible that the role of wives is important, especially in financial management (Burmana et al., 2010; Putrianti, 2007). Fishermen's wives have a dual role, namely as breadwinners when the husband's income is not sufficient to meet household needs (Najmi \& Fitrisia, 2019). Most of the area of Labuhan Bada's District consists of the coast, the coastal 
area is an area inhabited by people with distinctive family characteristics. Coastal is an area that has fishery potential, however, basically, coastal communities who are partly fishermen are still synonymous with poverty, until now it is still a classic coastal phenomenon. Not a few coastal communities in Labuhan Bada's District still live below the poverty line with low income. Poverty seems to be an inevitable part of fishermen's life in Labuhan Bada's District. The higher life purpose of bringing fishermen's wives in Labuhan Bada's District must work to divide their time between work and family to help their family's economy. This study aims to reveal the experiences of fishermen's wives working in balancing the dual roles of work and family, as well as the factors that can influence it.

\section{Methods}

This study uses a qualitative method with a phenomenological approach. This study seeks to deeply understand the role of fishermen's wives in Labuhan Bada's District, Sumbawa Regency, as women who have to work for their families and their roles as housewives, dig up information about the context of fishermen wives' daily lives in Labuhan Bada's District and try to understand the meaning of events. and everything related to her experience as a woman / wife who works and takes care of the household.

The selection of research subjects was based on purposive sampling technique. Purposive sampling is generally chosen after the initial survey or interviews in the field to ensure that the people selected in the study display the appropriate criteria in the study (Sugiyono, 2011).

The data collection method used in this study was semi-structured in-depth interviews. In this study, the researcher first made a framework of the subject matter that would be submitted to participants in the form of interview questions (interview schedule), interview questions addressed to participants were open.

The data analysis technique in this research uses the Interpretative Phenomenological Analysis (IPA) technique. The science approach aims to explore the subject's meaning to personal and social life in detail (Smith et al., 2009). Furthermore, they are explaining that science data analysis techniques are considered appropriate because science seeks to examine how a person interprets important experiences in his life in a natural setting.

\section{Results and Discussions}

Based on the results of data analysis, the researcher managed to conclude that there were five main themes including; a picture of life at work, the dynamics of life in the family, a picture of life undergoing multiple roles, the factors that influence the dual role of fishermen's wives and exploration of achieving balance in playing multiple roles. The five main themes summarize the super-ordinate themes which are presented in Table 1.

Table 1. Main Theme and Super-Ordinate Theme

\begin{tabular}{ll}
\hline \multicolumn{1}{c}{ Main Theme } & \multicolumn{1}{c}{ Super-Ordinate Theme } \\
\hline Picture of life at work & 1. The drive to work \\
& 2. Benefits during work \\
& 3. Experience in work \\
\hline The dynamics of life in the family & 1. Understand the role of being a housewife stairs \\
& 2. Understand the meaning of a family \\
& 3. Understand the role of caregiver her children \\
\hline The images of life play a dual role & 1. Role benefits in work and roles in family \\
& 2. Problems in work and family \\
\hline Factors affecting the dual role of & 1. Individual and family background \\
fishermen's wives & 2. Role orientation at work and in the household \\
& 3. Priorities in life and home stairs \\
& 4. Family support at work \\
5. Support the social environment
\end{tabular}


The social economy of fishing communities is through job diversification among housewives (Febi \& Budiman, 2017; Lubis, 2018). By diversifying jobs, it is hoped that fishermen's income sources will be more diverse and access to economic sources will be wider and more flexible. Every fisherman housewife to try hard and work collectively to achieve a better life. The role of being a housewife in a family and working to help the family economy begins when fishermen's wives choose to work after marriage. The encouragement of fishermen's wives to keep working after marriage is due to uncertain family income. This is also because their husband's catch depends on the season. Erratic season affects the fishermen's catch. One of the encouragement of fishermen's wives to work is to actualize their potential and abilities and to meet family needs. The fishermen's wives in Labuhan Bada's District besides selling the fish that their husbands catch, they also process the fish into salted fish. Women interpret work as selfactualization because they feel they have the ability. By working, you will get an honor, be able to develop yourself, hone your personality, become an independent person and focus on positive things.

The wife of fishermen in Labuhan Bada's sub-district even though they work, they still have duties and responsibilities as housewives such as preparing food, cleaning the house, taking care of their children and husbands and managing family finances. They make the experience they get at work as motivation to stay enthusiastic in helping the family economy. The duty of a housewife as a family accountant is to manage family income and budget as well as possible (Al Qarasi, 2003). The wife of a fisherman in Labuhan Bada's District in her daily life with her family also plays her role as a mother for her children. They continue to carry out their role in educating and caring for their children when they return from their activities of selling the fish that their husbands catch, this they do so that their children will still get love. The role of mother for children includes the duty of a mother to educate and care for her children by creating a psychological and psychological climate that is full of love, patience, calm and warmth so that it can stimulate children's growth towards maturity (Gunarsa \& Gunarsa, 2000). Fishermen's wives in family life also have a supporting role for their husbands in carrying out fishing activities. Social support will be more meaningful to someone when provided by people who have a significant relationship with the individual concerned such as parents, spouses (husband or wife), children and other families (Tylor et al., 2009). The fishermen's wives in Labuhan Bada's sub-district help prepare everything their husbands need, starting from making nets, providing the food needed while fishing and the fishermen's wives drying the fish caught by their husbands by processing the fish into salted fish and selling them in the market. Emotional support is support that involves empathy, attention, care, positive attention and encouragement to others (Sarafino \& Smith, 2011).

The wife's ability to carry out business productivity, the ability to apply technology and group collaboration can increase her family's income (Lubis, 2018). For the sake of their families, fishermen's wives consider that work is an obligation that they have to do so that their family can get a decent life, their children can also get a proper education. The wife of fishermen in Labuhan Bada's District realizes that their husband's income only depends on the catch of fish they get from fishing activities, that's why fishermen's wives participate in helping the family economy and helping their husbands through processing the fish they catch into salted fish and selling fish, either in the form of fresh or salted fish. Fishermen's wife in carrying out a dual role has a strategy, namely by managing time, asking for help from others, shortening the physical distance in the realm of the role and communication strategies. Individuals use several strategies in integrating demands in work with household tasks, namely by re-adjusting the problems between work and household (Allen et al., 2014). This strategy is divided into four broad categories, namely; (1) behavioral strategies related to the multiple roles that are carried out; (2) temporal strategies related to time management for family and work; (3) physical strategy in the form of limiting the distance between the realm of roles and (4) communication strategy, this strategy is important for fishermen's wives because even though they play multiple roles they do not forget their duties and responsibilities as wives and mothers of their children. The factors that affect work-family balance in four categories, namely first, workplace factors, second, family factors, third, social environmental factors and fourth, other factors related to a person's demographics (Widyaningsih \& Muflikhati, 2015). Factors that influence fishermen's wives in achieving work-family balance are in the form of social support they get in carrying out every role, whether from work, family or other social support. Social support can be in the form of feelings of comfort, appreciation, attention or assistance that someone gets from other people or other groups, support is needed by individuals in dealing with stressful situations (Sarafino \& Smith, 2011).

The lack of independence will have an impact on the income of fishermen's families, for this reason the role of fishermen's wives is very important in helping the family economy (Kumalasari et al., 2018). The self-concept possessed by fishermen's wives also influences them in achieving a balance of multiple roles because it affects their views and priorities in carrying out their roles. Apart from self-concept, emotional intelligence also affects the achievement of work-family balance. Emotional intelligence has a 
positive correlation to work-family balance. Emotional intelligence is related to the adaptive ability of individuals to recognize emotions, express emotions, regulate emotions and manage emotions for themselves and others (So et al., 2013). The wife of a fisherman in Labuhan Bada's District feels happy in carrying out her dual role and feels she can enjoy every role that is carried out, also indicates an active participation in each of her roles. Work-family balance is an overall assessment of the level of satisfaction and effectiveness of individuals in carrying out roles in the realm of work and family in accordance with their individual life values at a certain point in time. The benefits of achieving a work-family balance are that it can improve the quality of individual life, because individual involvement in several roles protects individuals from the negative effects of one role and is responsive in facing demands (Greenhaus \& Allen, 2011). Fishermen's wives have a high commitment to their work, this can be shown by loyalty and positive behavior such as being active in helping their husbands and not only selling fish in the market but also processing the fish into salted fish. The fishermen's wife's commitment to continue to carry out their roles as housewives and their success in carrying out multiple roles keeps their communication and relationship with their husbands and children intact. Workers who are able to achieve work-family balance will have commitment and loyalty to the workplace and behave positively at work. In life outside of work, individuals who are able to harmonize their dual roles (work and family) will have positive benefits in personal life, family, marriage satisfaction, free time and time for family (Greenhaus \& Allen, 2011; Lazar et al., 2010).

Women had enough time to finish the job responsibility. Most of the economic activity in coastal areas involving women. The division of work system has placed women as the ruler of the coastal economic activity. The impact of this system of work was women dominated in the affairs of the household economy and important decisions in the household. Thereby, women were not positioned as a supplement but were complement to maintain the viability of the household (Farihah, 2015). The wife of fishermen in Labuhan Bada's Subdistrict, Sumbawa Regency, makes working as an obligation, whatever they can do, they will do for their loved ones. Besides selling fish in the form of fresh fish to the market, some fishermen's wives also process the fish caught by their husbands into salted fish, then sell the fish to the market, when the fish is not sold, some are consumed by themselves with their families. The fishermen's wife's income is greatly influenced by the catch of their husbands. Likewise, when their husbands are not at sea because of bad weather or because their husbands are sick, what is done by fishermen's wives is to help their husbands knit nets that can be used to catch fish on the shoreline as long as the weather is not supportive and as long as their husbands are sick, as for fish. which is obtained later processed into salted fish and then sold in the market, some of it is also consumed by themselves. Fishermen's wives also take care of their husbands and children in between their time when they are at home, doing all their household activities. The results obtained by the fishermen's wives while they are working greatly help their family's economy, they can meet the daily needs of the family and can send their children to a higher level. The wife of fishermen in Labuhan Bada's sub-district can always live in harmony with their neighbors and relatives, it is proven that when they need assistance, their neighbors help both in terms of providing loan assistance in the form of money or helping them in other activities such as when there is a marriage activity from one of them. their families, neighbors came to help in giving donations in cash and in kind, as well as to help with necessary activities during the wedding ceremony.

\section{Conclusion}

Based on the results of data analysis, the researcher managed to conclude that there were five main themes including; a picture of life at work, the dynamics of life in the family, a picture of life undergoing multiple roles, the factors that influence the dual role of fishermen's wives and exploration of achieving balance in playing multiple roles. The role of being a housewife in a family and working to help the family economy begins when fishermen's wives choose to work after marriage. The encouragement of fishermen's wives to keep working after marriage is due to uncertain family income. This is also because their husband's catch depends on the season. Erratic season affects the fishermen's catch. One of the encouragement of fishermen's wives to work is to actualize their potential and abilities and to meet family needs. The fishermen's wives in Labuhan Bada's District besides selling the fish that their husbands catch, they also process the fish into salted fish. Women interpret work as self-actualization because they feel they have the ability. The wife of fishermen in Labuhan Bada's Subdistrict, Sumbawa Regency, makes working as an obligation, whatever they can do, they will do for their loved ones. Besides selling fish in the form of fresh fish to the market, some fishermen's wives also process the fish caught by their husbands into salted fish, then sell the fish to the market, when the fish is not sold, some are consumed by themselves with their families. The fishermen's wife's income is greatly influenced by the catch of their husbands. Likewise, when their husbands are not at sea because of bad weather or because their 
husbands are sick, what is done by fishermen's wives is to help their husbands knit nets that can be used to catch fish on the shoreline as long as the weather is not supportive and as long as their husbands are sick, as for fish. which is obtained later processed into salted fish and then sold in the market, some of it is also consumed by themselves. Fishermen's wives also take care of their husbands and children in between their time when they are at home, doing all their household activities. The results obtained by the fishermen's wives while they are working greatly help their family's economy, they can meet the daily needs of the family and can send their children to a higher level.

\section{References}

Al Qarasi, B. S. (2003). Seni Mendidik Islami: Kiat-kiat Menciptakan Generasi Unggul. Pustaka Zahra.

Allen, T. D., Cho, E., \& Meier, L. M. (2014). Work-family boundary dinamics. Anual Review of Psychology and Organizational Behavior, 1, 99-121.

Andrade, C. (2018). Work-Life Balance: Demands, Resources and Reconciliation Strategies. DEDiCA, 1(8), 117-130. https://doi.org/10.30827/dreh.v0i8.6913

Anoraga, P. (2009). Psikologi Kerja. Rineka Cipta.

Ariwidodo, E. (2016). Pekerja Perempuan Pesisir Sektor Pembudidayaan Rumput Laut Dalam Perspektif Analisis Gender di Pakandangan Tengah Kabupaten Sumenep. Nuansa, 13(2), 329-356. https://doi.org/10.19105/nuansa.v13i2.1103

Burmana, Lovely, B., \& Faturochman. (2010). Pengaruh Kepribadian Tangguh Dan Konflik Peran Ganda Terhadap Kinerja. Universitas Gajah Mada.

Farihah, I. (2015). Etos kerja dan kuasa perempuan dalam keluarga: Studi kasus keluarga Nelayan, di brondong, Lamongan, Jawa Timur. PALASTREN, 5(1).

Febi, F., \& Budiman, I. (2017). Pembangunan Ekonomi Keluarga Perspektif Islam (Studi Analisis Keluarga Nelayan Kota Lhokseumawe). J-EBIS (Jurnal Ekonomi Dan Bisnis Islam), 1(1). https://doi.org/10.32505/jebis.v1i1.74

Gauche, C., Beer, L. T. de, \& Brink, L. (2017). Managing employee well-being: A qualitative study exploring job and personal resources of at-risk employees. South African Journal of Human Resource Management, 15(1), 1-13. https://doi.org/10.4102/sajhrm.v15i0.957

Greenhaus, J. H., \& Allen, T. D. (2011). Work-family balance: A review and extension of the literature. Handbook of Occupational Health Psychology (2nd ed.). American Psychological Association.

Gunarsa, S. D., \& Gunarsa, Y. S. D. (2000). Psikologi Praktis Anak, Remaja dan Keluarga. PT BPK Gunung Mulia.

Handayani, A., Maulia, D., \& Yulianti, P. D. (2012). Kinerja Dosen Berdasarkan Konflik Kerja Keluarga dan Motivasi berprestasi.

Herdiansyah, H. (2016). Gender Dalam Prespektif Psikologi. Salemba Humanika.

Hidayati, N. (2015). Beban Ganda Perempuan Bekerja. MUWAZAH, 7(2).

Kumalasari, B., Herawati, T., \& Simanjuntak, M. (2018). Relasi Gender, Tekanan Ekonomi, Manajemen Keuangan, Strategi Nafkah, dan Kualitas Hidup pada Keluarga Nelayan. Jurnal Ilmu Keluarga Dan Konsumen, 11(2), 108-119. https://doi.org/10.24156/jikk.2018.11.2.108

Lazar, I., Osoian, C., \& Ratiu, P. (2010). The role of work-life balance practices in order to improve organizational performance. European Research Studies, 13(1), 201-214.

Lubis, A. S. (2018). Pembentukan Jiwa Entrepreneurship Bagi Para Istri Nelayan Melalui Pelatihan Pembuatan Greeble. Dinamisia, 2(1), 22-31. https://doi.org/10.31849/dinamisia.v2i1.805

Mulyadi, A. (2011). Perempuan Madura pesisir meretas budaya mode produksi Patriarkat. Karsa, 19(2).

Murtiningrum, A. (2005). Analisis pengaruh konflik pekerjaan-keluarga terhdap stres kerja dengan dukungan sosial sebagai variabel moderasi. Universitas Diponegoro.

Najmi, N., \& Fitrisia, A. (2019). Peranan Perempuan Nelayan Kota Padang dalam Membantu Ekonomi Keluarga. Diakronika, 19(1), 1-20. https://doi.org/10.24036/diakronika/vol19-iss1/75 
Putrianti, F. C. (2007). Kesuksesan peran ganda wanita karis ditinjau dari dukungan suami, optimisme, dan strategi coping. Indigenious, Jurnal Ilmiah Berkala Psikologi, 9(1), 3-17.

Saleha, Q., Hartoyo, H., \& Hastuti, D. (2008). Manajemen Sumberdaya Keluarga: Suatu Analisis Gender Dalam Kehidupan Keluarga Nelayan di Pesisir Bontang Kuala, Kalimantan Timur. Jurnal Ilmu Keluarga Dan Konsumen, 1(2), 118-130. https://doi.org/10.24156/jikk.2008.1.2.118

Sarafino, E. P., \& Smith, T. W. (2011). Health Psychology: Biopsychosocial Interactions (7th ed.). John Willey \& Sons Inc.

Smith, J. A., Flowers, P., \& Larkin, M. (2009). Interpretative Phenomenological Analysis. SAGE Publications, Inc.

So, J., Parsons, A., \& Yap, S. (2013). Corporate branding, emotional attachment and brand loyalty: the case of luxury fashion branding. Journal of Fashion Marketing and Management: An International Journal, 17(4), 403-423. https://doi.org/10.1108/JFMM-03-2013-0032

Sugiyono. (2011). Metode Penelitian Kuantitatif, Kualitatif, dan R\&D. Alfabeta.

Tylor, S. E., Peaplau, L. A., \& Sears, D. O. (2009). Psikologi Sosial. Kencana.

Valk, R., \& Srinivasan, V. (2011). Work-Family Balance of Indian Women Software Professionals: A Qualitative Study. IIMB Management Review, 23(1). https://doi.org/10.1016/j.iimb.2011.01.006

Widyaningsih, E., \& Muflikhati, I. (2015). Alokasi Pengeluaran Dan Tingkat Kesejahteraan Keluarga Pada Keluarga Nelayan Bagan. Jurnal Ilmu Keluarga Dan Konsumen, 8(3), 182-192. https://doi.org/10.24156/jikk.2015.8.3.182

Zuhriah, Z. (2016). Kuliwa: A Cultural Identity of the Local People of Mandar, West Sulawesi. Dinika: Academic Journal of Islamic Studies, 1(2), 165-175. https://doi.org/10.22515/dinika.v1i2.127 